\title{
ACRL joins national initiative on faculty roles and rewards; seeks member input
}

The Association of College and Research Libraries has been invited to participate in a national movement to re-examine the performance criteria by which faculty tenure and promotion are awarded. ACRL and severa! other discipline-based associations in higher education believe it is necessary for academia to move beyond the "publish or perish" model of assessing faculty effectiveness.

The ACRL Board of Directors has appointed a task force to represent the association in the Institutional Priorities and Faculty Rewards Project, which is being coordinated by Syracuse University's Center for Instructional Development. To date, more than fifteen professional associations (such as the American Historical Association, the American Philosophical Association, and the American Chemical Society) have participated by drafting statements that describe the range of activities appropriate for faculty in their discipline and deserving of recognition through the promotion and tenure system.

The ACRL Institutional Priorities and Faculty Rewards Task Force is charged with drafting a similar statement for academic librarianship. It is hoped that such a statement may be used on individual campuses as a basis for assessing the performance of librarians whether they have faculty status or not. An important aim of the document is to clarify and support the use of performance criteria beyond the "publish or perish" model from which other disciplines also wish to move. According to Robert M. Diamond, assistant vice-chancellor for instructional development at Syracuse University and director of the institutional priorities and faculty rewards program:

"Another premise of our efforts is that having disciplinary societies set out a full range of activities upon which tenure and promotion decisions can be based will help change the priorities for faculty members. We hope that this will free them to focus more on inproving their teaching, improving curricula, and working in community activities that can benefit from their particular expertise. It also should increase the recognition of contribu- tions which are frequently undervalued by traditional promotion and tenure criteria."

Many librarians with faculty status have argued that the classic faculty emphasis on research puts librarians at an enormous disadvantage due to the demands of full-year contracts, 40-hour work weeks, and the need to keep up with day-to-day responsibilities.

Many librarians, with and without faculty status, have been frustrated that their important roles in information organization, information evaluation, and provision of access to information are not given sufficient recognition by the typical campus reward structure.

The task force hopes to address these issues in its statement and is asking ACRL members to help identify related concerns to be considered. All ACRL members are invited to discuss the task force's charge at an open forum at ALA Midwinter on Saturday, February 15, 2:00-4:00 p.m. Ed. note: The task force is tentatively scheduled to meet in Salon A and $B$ of the Marriott Metro Center but check the conference program as locations may change.

Members of the task force are: W. Bede Mitchell (chair), Appalachian State University; Althea Jenkins, ACRL executive director; Brian C. Kelley, Palm Beach Community College; Rush G. Miller, University of Pittsburgh; Larry Oberg, Williamette University; Carol Parke, Syracuse University; and Glorianna St. Clair, Penn State University.-W. Bede Mitchell, associate university librarian, Appalachian State University

\section{Related readings}

Boyer, Ernest L. Scholarship Reconsidered: Priorities for the Professoriate. Princeton, N.J.: Carnegie Foundation for the Advancement of Teaching, 1990.

Diamond, Robert M. and Bronwyn E. Adam, editors. The Disciplines Speak; Rewarding the Scholarly, Professional, and Creative Work of Facult)! Washington, D.C.: American Association of Higher Eclucation, 1995. Recognizing Faculty Work: Reward Systems for the Year 2000. San Francisco: Jossey-Bass, 1993. 